\title{
THE DIVIDEND POLICY OF CAPITAL GROUPS AND OTHER DIVIDEND COMPANIES LISTED ON THE WARSAW STOCK EXCHANGE - RESEARCH RESULTS
}

\author{
Bartlomiej Jabłoński \\ University of Economics in Katowice \\ e-mail: bartlomiej.jablonski@ue.katowice.pl \\ ORCID: 0000-0002-9398-017X \\ (C) 2021 Bartłomiej Jabłoński \\ This work is licensed under the Creative Commons Attribution-ShareAlike 4.0 International License. \\ To view a copy of this license, visit http://creativecommons.org/licenses/by-sa/4.0/
}

Quote as: Jabłoński, B. (2021). The dividend policy of capital groups and other dividend companies listed on the Warsaw Stock Exchange - research results. Financial Sciences, 26(1).

DOI: 10.15611/fins.2021.1.01

JEL Classification: G11, G30, G32, G35

\begin{abstract}
Summary: The aim of the article was to present research on the characteristics of the dividend policy of capital groups and other dividend companies listed on the Warsaw Stock Exchange that paid dividends in 2012-2019 and to undertake a critical evaluation. The research relates to the methods of describing the dividend policy implemented by companies listed on the Warsaw Stock Exchange, which publish consolidated financial statements (capital groups) and measures of the system of payout of dividends by these entities. Based on the conducted research, it should be stated that capital groups are of a higher average annual dividend growth rate than companies publishing only separate financial statements, whilst the latter boast a higher average cumulative rate of dividends. The conducted research shows that the parent companies do not show whether they receive dividends from their subsidiary companies. However, based on the Spearman's Rho analysis and the Pearson linear correlation coefficient for the analysed companies, it was found that there was a statistically significant link for capital groups and other companies between the average annual rate of return and the cumulative rate of dividends, and only for the remaining companies, a positive link between the average annual dividend growth rate and the cumulative rate of dividends (yet, this has not been confirmed by the Pearson's linear correlation coefficient). The added value and application value are recommendations regarding the attractiveness of investing in dividend companies - capital groups or companies without related entities.
\end{abstract}

Keywords: capital group, dividend policy, determinants of dividend policy, Spearman's rank correlation coefficient. 


\section{Introduction}

A company's dividend policy defines the rules of distribution of the generated profit - what part of it will be transferred to investors in the form of a dividend, and what part will remain in the company for other use. The number of factors (determinants) that may affect the dividend policy, as well as changes in the form, frequency or amount of dividend payout, are widely described in foreign and domestic literature (e.g. J.H.von Eije, W.L. Megginson, H. DeAngelo, L. DeAngelo, D. Skinner, M. Jagannathan, C.P. Stephens, M.S. Weisbach, E.F. Fama, K.R. French, G. Grullon, D.L. Ikenberry, A. Brav, J.R. Graham, C.R. Harvey, R. Michaely, R. Tuzimek, M. Kowerski, M. Sierpińska, A. Szablewski, T. Słoński, B. Jabłoński, J. Kuczowic). A division into micro and macroeconomic determinants of dividend policy is assumed, which include investor preferences regarding dividend payout, legal restrictions on dividend payout, investment funds' requirements as to constant income from capital, availability of effective investment opportunities and costs of issuing new shares, the life cycle of the enterprise, the size of cash flows, availability of cash, stability of profits and the need to maintain control over the entity.

Changes in the level of dividend payout cause diversified behaviour of capital market investors, which can be classified as patterns of investor behaviour (Brigham \& Houston, 2015, p. 585; Głodek, 2004, p. 144) (or managers of companies paying dividends). The study found that the most important ones include the theory of 'dividend stickiness' and 'feeding with dividends'. Dividend stickiness explains why companies that paid dividends in the base year are likely to pay them in the next period, and it occurs because the issuing bodies are reluctant to pay out dividends when their future is uncertain. Still, those companies that have continuously paid dividends will try to do so and not make changes in order not to be excluded from the group of dividend companies. Another fascinating explanation of the behaviour of managers is the feeding with dividend theory, which states that managers who want to determine the increase in the price of company shares may start paying dividends or increase their level. In addition, if the company's capitalization affects additional management bonuses, dividends may constitute an essential tool in pursuing their private interests. Therefore, while the dividend policy of capital groups may mean a balance between the expectations of capital market investors regarding the payout of dividends and the investment needs of the parent company, a balance between dividend payouts made by the parent company and dividends obtained from subsidiary companies of the capital group.

It is worth mentioning that there are also studies on dividend policy with the distinction of capital groups in selected countries. However, their number compared to studies on dividend policy issues is much lower (N.B. Lahbane, M. Al-Nawaiseh, R. Goplan, V. Nanda, A. Seru A, M. Sopata, M. Mikić, T. Horvatinović). However, they do not relate to dividend policy issues within capital groups (dividend policy of the parent company may differ from the rules for the distribution of the financial 
result of associates within the group). Moreover, no comparisons were undertaken of dividend capital groups with entities paying dividends but publishing only separate financial statements to indicate the strength and direction of relationships between changes in the average annual rate of return, average annual dividend growth rate, total dividends and the cumulative rate of dividends.

This article refers to the characteristics of the dividend policy of capital groups listed on the Warsaw Stock Exchange. The aim was to present research on the characteristics of the dividend policy of capital groups and other dividend companies listed on the Warsaw Stock Exchange that paid dividends in 2012-2019 and undertake a critical evaluation; some companies that paid dividends continuously in the analysed period or did not pay them just once were selected for the research. The author intended to identify the features of these companies from the perspective of the description of the dividend policy, the degree of its implementation, as well as the specificity of the dividend payouts themselves.

As part of the research, a dependency analysis was also conducted separately for dividend capital groups and other dividend companies, based primarily on the research on the correlation (Pearson's linear correlation coefficient and Spearman's (or Spearman's Rho) rank correlation coefficient) of changes in the average annual rate of return, average annual dividend growth rate, total dividends and the cumulative rate of dividends. The use of Spearman's Rho in the research allows for the determination of whether there is a correlation between two variables (when the variables do not meet the assumptions of parametric tests), such as the normality of the distribution or the quantitative nature of the tested variables. The use of Pearson's linear correlation coefficient in the research is only intended to compare the results with Spearman's Rho.

\section{Literature review and research hypotheses development}

Companies listed on the stock exchange often do not have a dividend policy in place, but despite this, they systematically share part of the profit with shareholders. Based on the conducted research, it was also noted that companies that have a developed dividend policy in place do not necessarily comply with it (Jabłoński, 2018, 2019). Therefore, in creating the company's image, the corporate governance relating to the adopted and applied dividend policy is essential in investor relations, which focus on the company's relations with investors, among whom shareholders, i.e. co-owners, play a special role (Dziawgo, 2011, p. 15). Dividend payouts could also be divided in terms of sectors and ownership. Companies with State Treasury shareholding and from sectors of crucial importance to the economy more often decide to implement the dividend policy (Piątkowska, 2019, p. 77). Adopting the corporate finance and financial markets perspective emphasizes the importance of investor relations as a 'financial information filter', whose main task is to present the clearest picture of the company's financial situation and its prospects for development (Lukasik, 2013, 
p. 14). Investor relations, supporting the transparency of the entity to the greatest extent possible, act as a generator of the company's value (Dziawgo, 2011, p. 62). Some investors may emphasize the inflow of cash due to the payout of dividends, which they may spend on their consumption or investment needs. Unfortunately, if the decision is made to maintain the current ownership structure, the management board can decide to keep the profit and pay a lower dividend (Łukasik \& Błach, 2016, p. 87).

The dividend policy of the capital group can be considered from the parent company's perspective (often listed on the stock exchange) and that of subsidiary companies. The concept of capital groups (or holding companies) is related to the consolidation of financial statements. Entities linked by capital to other entities often form complex ownership structures, the results of which are analysed by various interest groups, including capital market investors. For this reason, there is a need to consolidate the financial results and publish a consolidated financial statement (Gmytrasiewicz \& Karmańska, 2006, pp. 677-685). Such a statement presents a broader scope of information than the separate financial statements of entities. This applies particularly to the property and financial condition and the levels of financial results within the scope of the entire capital group, which is treated as a single (artificial) economic entity.

The consolidation of financial statements allows for a complete analysis of the parent company and its subsidiary companies, regardless of the place where the revenues and costs are generated. Consolidation of the statements of the capital group eliminates the practice of shifting revenues and costs, using capital links or artificial commercial transactions at inflated prices within the group.

The parent company of a capital group is defined in terms of the criterion of holding majority voting rights or control exercised on the basis of other guidelines. This means that such an entity can direct the operational and financial policy of another enterprise to gain economic benefits. In turn, only a capital company can become a subsidiary company and dependence on the parent company results from its control ${ }^{1}$ (Art. 3 par. 1 point 44 of the Accounting Act, Journal of Laws of 2016, item 1047 as amended).

The dividend policy of the subsidiary companies of the capital group is subject to as many similar determinants as the dividend policy of the parent company. However, some dividend payout factors do not apply to subsidiary companies. First of all, the signalling effect plays a minor role. Changes in the dividend payout by the parent company are subject to analyses and particular criticism from shareholders in the event of a reduction in the dividend payout level. For a subsidiary, the signalling effect is mild or vanishes completely as the shareholding structure is less dispersed and the dominant owner not only has complete knowledge of the reasons for changing

${ }^{1}$ Article 3 of the Accounting Act of September 29, 1994 (consolidated text Journal of Laws of 2016, item 1047 as amended). 
dividends, but also these changes may result from their direct decisions. Research conducted by Desai, Foley, and Hines Jr. (Desai, Foley, \& Hines, 2002) show that a similar number of subsidiary companies increases and reduces the payout of dividends ( $10 \%$ for each of the companies in the group of companies studied) to the parent company, while parent companies, if they change the level of dividends paid, rather increase it (20\% of the analysed companies) than reduce it (5\% of the analysed companies). If, in the initial period, the dividend policy proposed by the parent company is not applicable, in the long run subsidiary companies adjust their dividend payouts to the adopted (and somewhat imposed) profit distribution strategy. Moreover, the process is similar for both domestic and foreign subsidiary companies. In terms of the principles of distribution of the financial result, a similarity is often observed in the dividend policy of the parent company and its subsidiary companies. Such behaviour within the group may result from the willingness to maintain a constant balance of cash flows received from subsidiary companies and paid by the parent company to its shareholders.

A frequently reported objection by subsidiary companies regarding the imposed dividend policy is the reduced ability to generate profits at subsidiary level as a result of commercial settlements within the group. The parent company may influence the settlement prices with its subsidiary companies, thus gaining additional benefits at operational level. This is related to the problem of the transfer of funds to the parent company from its foreign branches. The most common forms of intra-group settlements are dividend payouts, licence fees, transfer pricing and forced reinvestments. The factors influencing the main channel of cash transfer to shareholders - dividends - include the effective tax rate on the transferred income, sources of financing, and currency limits and restrictions. Therefore, while subsidiary companies have limited ability to achieve high profits, , they also impose - often strict - dividend payout rules. However, this solution is supported by the concern of the majority owner of the subsidiary companies about the mismanagement of the management boards of the subsidiary companies. One solution is the residual dividend payout model, in which the management board of a subsidiary may recommend a lower dividend payout due to the implementation of highly effective or innovative investment projects. Such behaviour of the management boards of subsidiary companies should satisfy the parent company, as they show the willingness to use capital efficiently and avoid the accusation of mismanagement. In turn, the parent company may thus discipline the decisions of the subsidiary's management board regarding decisions on the distribution of the financial result and limit investment projects with low profitability and questionable implementation justification. This approach to the dividend policy is fundamental when it comes to subsidiary companies having their registered offices outside the country where the parent company operates. For foreign subsidiary companies, the imposed dividend policy is one of the methods of controlling these boards. Research by Desai, Foley and Hines (Desai, Foley, \& Hines, 2002) shows that subsidiary companies of 
multinational corporations equally often reduce and increase dividend payout without paying attention to the signalling effect, which, in turn, is essential for the parent company operating in the capital market. The strength of this effect is particularly noticeable for those capital groups that are listed on international stock exchanges and strongly emphasize their dividend policy.

Another factor that significantly determines the payout of dividends by subsidiary companies is the tax regulations in force in the country of their registered office. The impact of this factor is powerful in countries with differences in taxation rates for dividends and capital gains. Shareholders are not particularly interested in a dividend if it is taxed more than capital gains, as this reduces the efficiency of investments in companies that pay out dividends. The research (Chetty \& Saez, 2005, pp. 791-833) showed that reducing the amount of taxes on dividends increases the rates of return on investment in the long run. However, based on (Kari, Karikallio, \& Pirttilä, 2009, pp. 1-41) and (Jacob \& Jacob, 2013, pp. 1-46) in 25 countries for 1980-2008, and in 24 OECD member states for 2000-2007, on the influence of tax policy on dividend policy, it is possible to indicate the preferences of the standard taxation system and the reduction of the total taxation of dividends. ${ }^{2}$ It is worth adding that average dividend rates and average payout rates were lower in countries with this taxation system. Deferral of tax liabilities by reinvesting profits by a subsidiary and no payout of dividends is common in international capital groups. However, obtaining higher dividends from subsidiary companies allows the parent company to meet its financial needs, including the payout of dividends to shareholders (Desai, Foley, \& Hines, 2007, pp. 5-26).

Other studies, (Altshuler \& Grubert, 2003, pp. 73-107) and (Desai, Foley, Hines, 2001, pp. 829-851), noted that companies can defer tax liabilities by investing profits in other foreign subsidiary companies instead of transferring them to parent companies. At the same time, subsidiary companies often finance investments with generated profit, reducing or even abandoning the payout of dividends.

Another factor determining the payout of dividends within the capital group is the pressure on the payout of dividends by the parent company's shareholders. Often these pressures are reflected in the internal dividend policy. The dividend policy established and respected by the parent company may affect the amount of obtained dividends which it expects from its subsidiary companies. Additionally, this emphasis is intensified by the degree of self-confidence of the managerial authority (Wrońska-Bukalska, 2018).

When referring to international research on the differences in dividend payouts between capital groups and entities operating independently, attention should be paid to their common features. Research conducted by Lahbane (2019, pp. 133-150) on 781 selected Indian companies listed on the National Stock Exchange (NSE) in

\footnotetext{
2 The standard system is one where corporate profits and shareholder income are taxed independently.
} 
1995-2015, divided into capital groups and independent entities, indicate that in terms of characteristics, companies associated within a capital group are larger, more profitable and more indebted than independent companies. Empirical results suggest that decisions regarding the dividend policy of companies associated with the capital group differ significantly from the decisions of independent entities. Issuing bodies not operating within capital groups are less willing to pay dividends, and the level of dividend payout is lower. However, capital groups pay dividends more often, and the level of dividend payout is higher, even if they are characterized by a large number of investments, high financial leverage and high business risk. Similar conclusions can be drawn from other studies (Goplan, Nanda, \& Seru, 2014, pp. 1102-1142). According to these authors, the dividend policy is influenced by the presence of capital groups - related companies with excess cash are willing to pay dividends, which increases the scale of investments of other companies of the capital group, whereas Al-Nawaiseh (2012, pp. 83-106) indicated that among the 62 analysed entities listed on the Amman Stock Exchange in 2000-2006, the ownership structure and links with other entities do not significantly determine dividend payouts. According to another study (Sopata, Mikić, \& Horvatinović, 2019, pp. 25-36), companies listed on the Zagreb Stock Exchange are less willing to pay dividends if they are part of a capital group; similar conclusions were provided by (Goldman, \& Viswanath, 2017, p. 567-610). Following the research, it was found that capital groups pay lower dividends as they are more willing to invest within the capital group.

To sum up, it should be stated that the dividend policy of subsidiary companies is conditioned by factors similar to the dividend policy of the parent company, but they are of less importance. The often indicated and the most important determinants of dividend payout within a capital group are corporate control, expectations of the parent company, and for foreign subsidiary companies, the possibility of reinvesting profits with tax benefits at the same time. In this case, it is difficult to point to the problem of information asymmetry or the signalling effect. To a greater extent, the dividend policy of subsidiary companies is determined by the dividend policy of the parent company (and therefore with similar determinants of the dividend policy) and the need to obtain funds from subsidiary companies, from which the parent company may partially cover dividend payouts to capital market investors.

Based on the literature review and the identified research gaps, hypotheses were formulated as follows:

$\mathrm{H}_{1}$ : Capital groups listed on the Warsaw Stock Exchange inform in their dividend policy about the principles of dividend payment by subsidiaries.

$\mathrm{H}_{2}$ : Dividend capital groups are characterized by a higher average annual dividend growth rate and cumulative rate of dividends than other dividend companies due to the greater possibilities of cash flow between the group companies.

$\mathrm{H}_{3}$ : Correlation of the average annual rate of return with the cumulative rate of dividends in the case of capital groups presents a stronger correlation than in other companies. 


\section{Sample selection and methodology}

The verification of the hypotheses will be carried out in the following stages:

1. Stage one - selection of companies listed on the Warsaw Stock Exchange that in the period 2012-2019 continuously paid dividends (eight years of dividend payout -28 companies) or characterized by a year break in the transfer of funds to shareholders (dividend paid seven times - seven companies). A year with no dividends allowed to investigate more companies. The research covered 35 entities publishing consolidated and/or separate financial statements (Appendix 1).

2. Stage two - preliminary research on the history of dividend payouts by the issuing bodies (selected in stage one), divided into companies publishing consolidated financial statements (capital groups - 31 companies) and those that publish only separate financial statements (other companies - four companies). The research included the analysis of the median and average values for the annual dividend growth rate, the annual rate of return and the cumulative rate of dividends.

3. Stage three - dividend policy research included:

3.1. research on the characteristics of the dividend policy divided into issuing bodies operating as capital groups and as companies with no subsidiary companies. The research was conducted based on the websites of the analysed companies (investor relations departments), their financial statements and other corporate documents of the listed entities (e.g. concerning corporate governance or issue prospectuses);

3.2. calculation of the Spearman rank correlation coefficient and as a supplement to Pearson's linear correlation coefficient separately for capital groups and other companies in terms of indicating the strength and direction of relations between changes in the average annual rate of return, average annual dividend growth rate, total dividends and the cumulative rate of dividends.

\section{Dividend policy of capital groups listed on the Warsaw Stock Exchange from 2012 to 2019 - research results}

\subsection{General research}

The research covered companies whose shares are listed on the Warsaw Stock Exchange. In order to select companies that paid dividends in 2012-2019 (for the period 2011-2018); 2020 was not included in the research due to an exceptional disturbance in the systematic payout of dividends by the stock exchange issuing bodies caused by the pandemic. For the purposes of the article, entities were selected that paid dividends continuously in the analysed period or did not pay them just in one year. Including companies with one period without dividend payout in the analysis increased the number of entities analysed from 28 to 35 companies. The dividend payout criterion (seven or eight times in eight years) was dictated by the 
need to analyse the actual dividend companies that distribute the financial result over a more extended period. Additionally, for the purposes of the research the selected companies were divided into dividend capital groups (defined as capital groups) and dividend companies that operate without subsidiary companies (defined as other companies). The sources of data were the websites of the issuing bodies and the investor relations department, the corporate documents of the stock exchange issuing bodies (e.g. on corporate governance, prospectuses) as well as separate and consolidated financial statements.

The preliminary comparison of the examined entities was carried out based on the measures of the annual dividend growth rate - the average annual dividend growth rate and the median of the annual dividend growth rate (Figure 1).

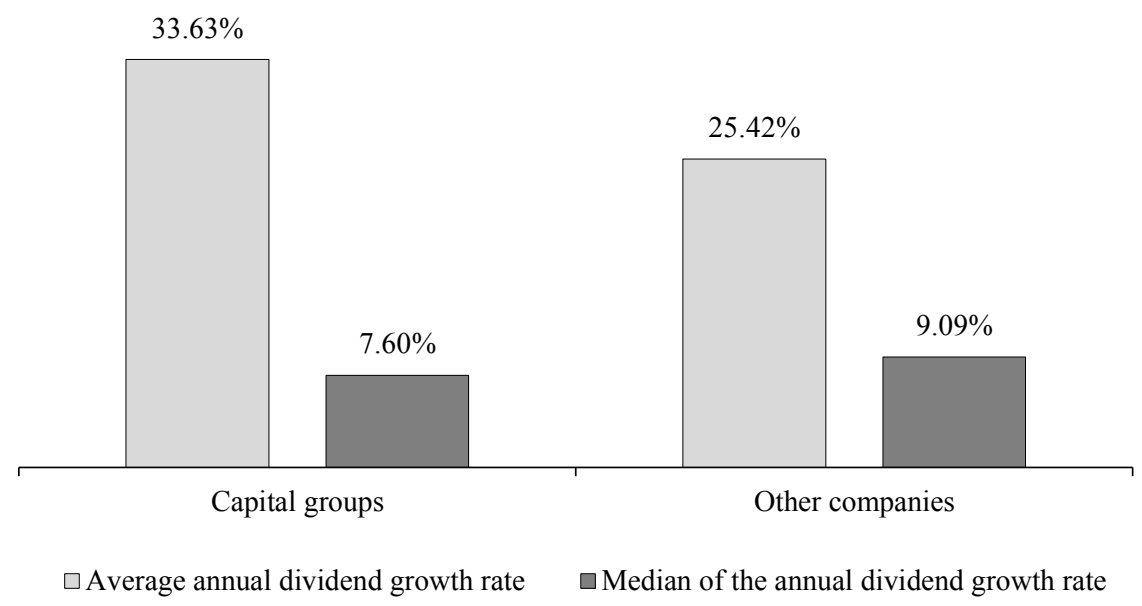

Fig. 1. Measures of the annual dividend growth rate of the analysed entities

Source: own research.

If the average growth rate is taken as the measure of the annual growth rate of paid dividends, companies consolidating financial results are characterized by a higher value (33.63\%). At this stage of the research, it is impossible to state whether the higher average increase in dividends paid is due to the fact of obtaining dividends from subsidiary companies or the adopted dividend policy. However, companies that do not operate as capital groups are characterized by a higher value of the median annual dividend growth rate $(9.09 \%)$.

When comparing both groups of entities with measures of average annual rates of return taking into account paid dividends, for companies not indicated as capital groups, the average annual rate of return and the median annual rate of return take higher values than for capital groups (Figure 2). 


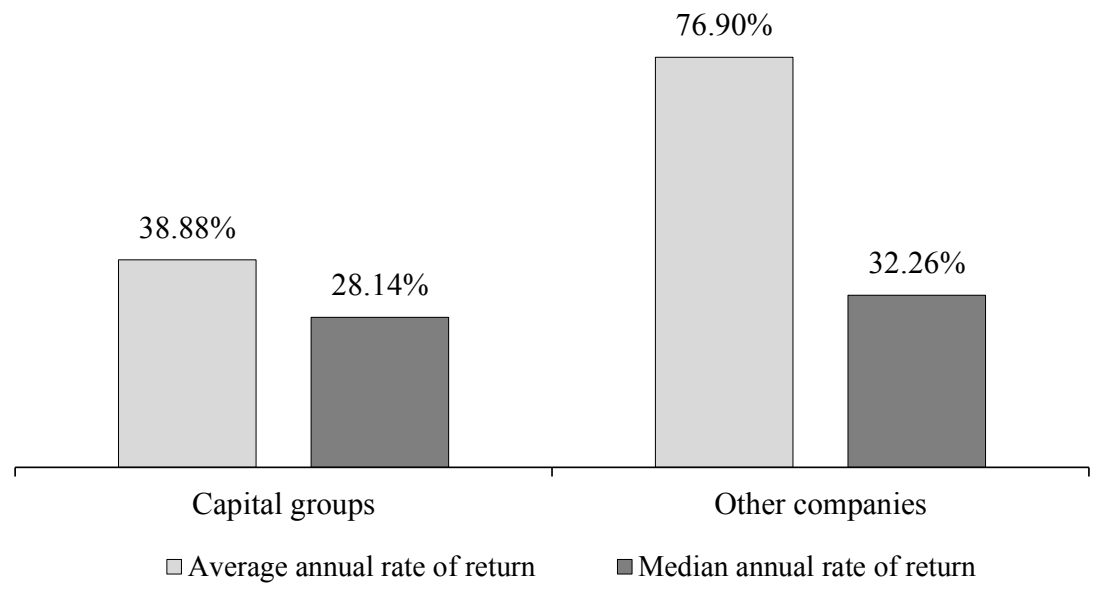

Fig. 2. Measures of the average annual rate of return of the analysed entities

Source: own research.

Regardless of the applied measure of the annual rate of return (average or median), companies publishing separate financial statements are characterized by a higher average annual increase in the share price than capital groups. The differences are apparent when comparing both groups of companies with the average annual rate of return (38.88\% for capital groups and $76.90 \%$ for the other selected companies). From the capital market investor's point of view, it is essential to what extent dividends are paid in relation to share prices (dividend rate). Considering this measure for long-term investments, a more reasonable measure is the ratio of the sum of dividends paid to the share purchase price (possibly the average share purchase price) - the cumulative rate of dividends, calculated as the sum of dividends paid in relation to the share price at the beginning of 2012.

The cumulative rate of dividends is calculated according to the formula:

$$
D Y_{S}=\frac{\sum_{t=1}^{n} D P S_{t}}{P_{t}} \times 100 \%,
$$

where: $D P S_{t}$ - Dividend Per Share received by the investor in year $t, P_{t}$ - Price of the acquisition of shares.

A comparison of both groups of analysed entities with measures of the cumulative rate of dividends is shown in Figure 3.

The average cumulative rate of dividends and the median of the cumulative rate of dividends of capital groups listed on the Warsaw Stock Exchange, calculated for 2012-2019, are lower than the same measures calculated for companies publishing only separate financial statements. This means that even if the parent companies in 


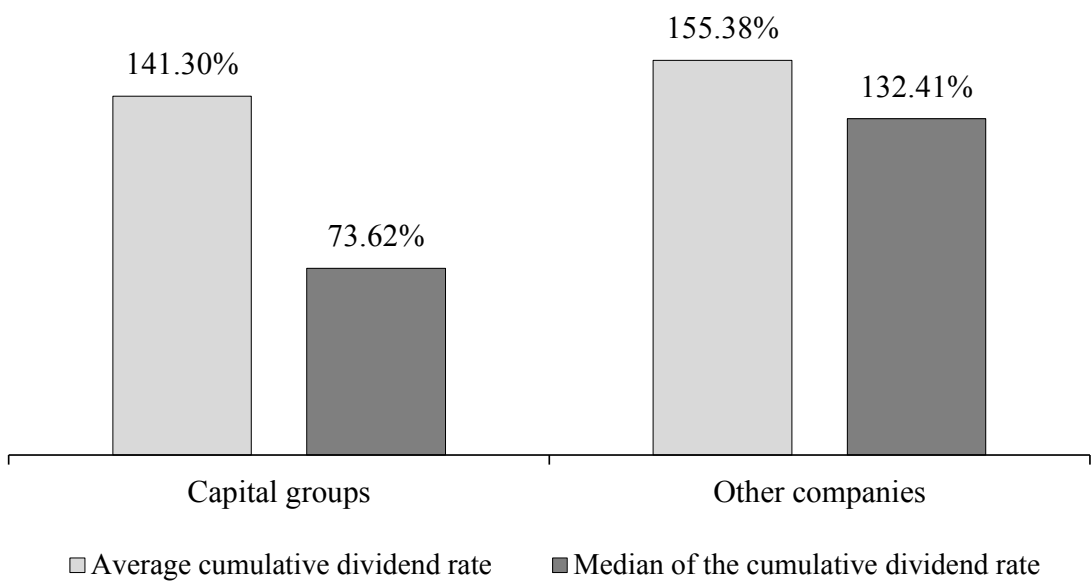

Fig. 3. Measures of the cumulative rate of dividends

Source: own research.

the capital group received dividends from subsidiary companies, it did not necessarily translate into higher dividends in relation to the share prices at the beginning of 2012 (Table 1).

Table 1. Parameters of the analysed companies

\begin{tabular}{|l|c|c|}
\hline \multicolumn{1}{|c|}{ Company parameters (\%) } & Capital groups & Other companies \\
\hline Average annual dividend growth rate & $33.63 \%$ & $25.42 \%$ \\
\hline Median of the annual dividend growth rate & $7.60 \%$ & $9.09 \%$ \\
\hline Average annual rate of return & $38.88 \%$ & $76.90 \%$ \\
\hline Median annual rate of return & $28.14 \%$ & $32.26 \%$ \\
\hline Average cumulative rate of dividends & $141.30 \%$ & $155.38 \%$ \\
\hline Median of the cumulative rate of dividends & $73.62 \%$ & $132.41 \%$ \\
\hline
\end{tabular}

Source: own research.

However, as shown in Table 1, they were characterized by a higher average annual dividend growth rate. This may mean that capital groups pay out low dividends in relation to share prices, but are characterized by a higher average dividend growth rate. The increase in paid dividends may be financed with the achieved results of the parent company, the subsidiary companies of the capital group, as well as obtained dividends from subsidiary companies. 


\subsection{Dividend Policy Research}

The research on dividend policy was related to the analysis and comparison of the dividend policy of capital groups with other companies selected to conduct the research. The research took into account the clarity of the description of the dividend policy on the company's website or other company documents, and the degree of detail in the description of the dividend policy. Additionally, the dependencies were analysed separately for capital groups and other companies regarding changes in the average annual rate of return, average annual dividend growth rate, total dividends and the cumulative rate of dividends.

When referring to the comparison of the characteristics of the dividend policy of capital groups with other companies that are not capital groups, it is noticeable that the description of the dividend policy of the parent companies is more transparent (Figure 4).

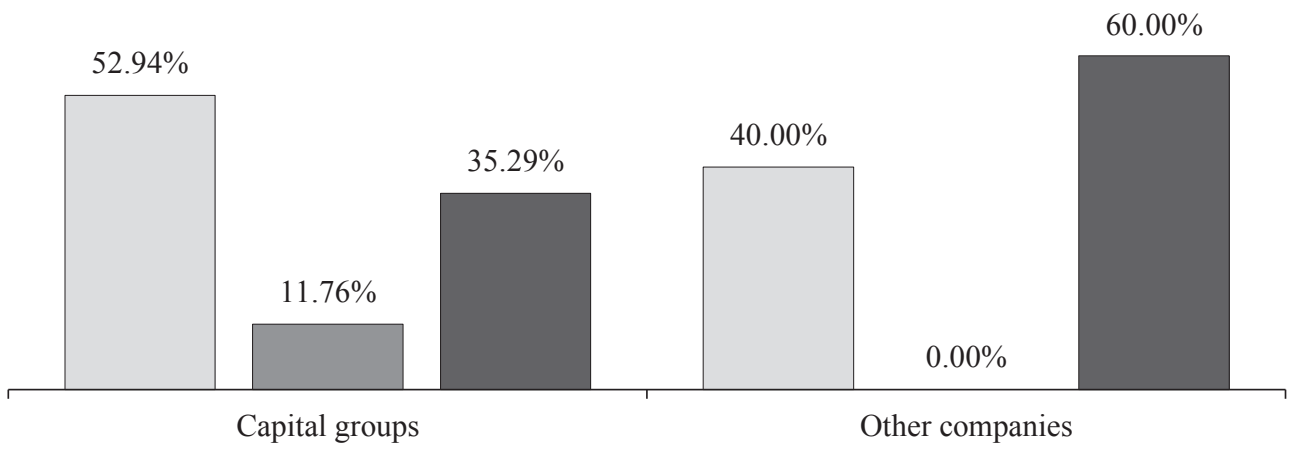

$\square$ 1. Dividend policy clearly described on the issuing body's website or company documents

$\square 2$. General statement that dividends are recommended by the Executive Board, Board of Directors or approved by the General Meeting of Shareholders

$\square$ 3. No dividend declaration

Fig. 4. Criteria for dividend policy analysis

Source: own research.

More than half of the analysed parent companies (52.94\%) from capital groups informed about the principles of distributing the financial result on websites or in the company's documents. In the case of the remaining companies, only $40 \%$ of them tried to provide information on the distribution of the financial result in this way, and there was the highest share of the issuing bodies ( $60 \%$ of the companies) who did not declare payout of dividends. Only $11.76 \%$ of capital groups generally stated that dividends were recommended by the board of directors or approved by the general meeting of shareholders. By grouping the obtained results of the comparison into clearly positive or negative, the share of the latter was even more significant (Figure 5). 


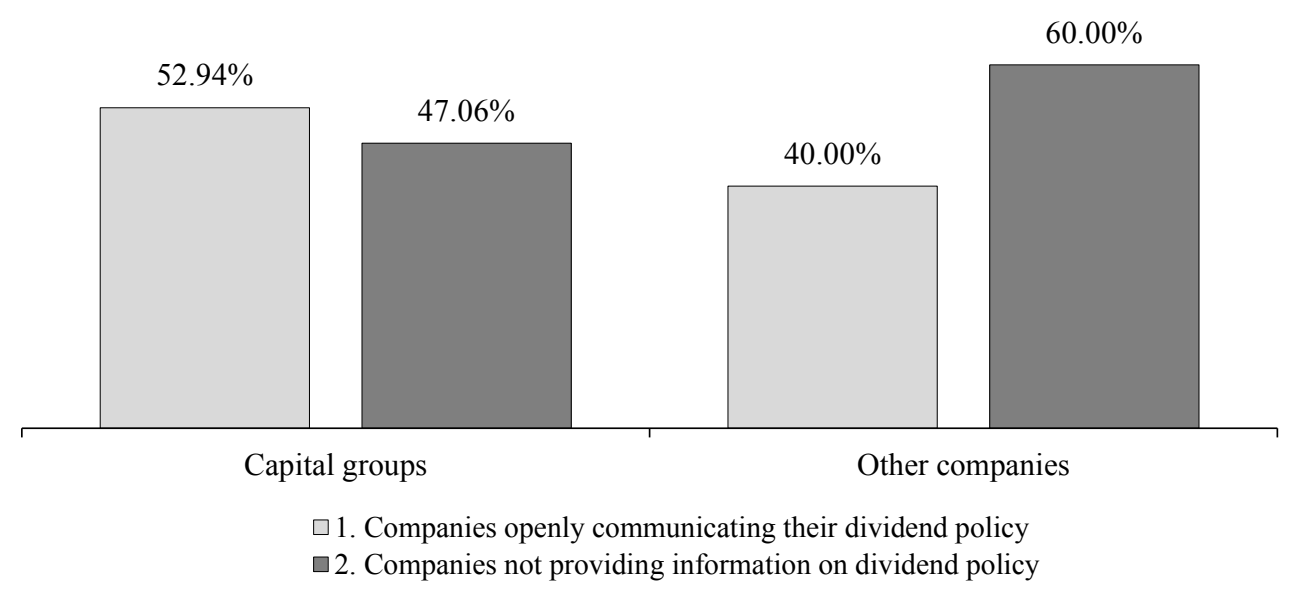

Fig. 5. Assessment summarizing the quality of communication of the dividend policy by capital groups and other dividend companies listed on the Warsaw Stock Exchange for 2012-2019

Source: own research.

As many as $60 \%$ of the analysed companies that are not capital groups did not provide specific information on their dividend policy, even though they paid out dividends. In turn, more than half of the analysed capital groups $(52.94 \%$ of the issuing bodies) openly informed about the adopted dividend policy. Later in the study, reference was made to the comparison of the characteristics of the dividend policy for both groups of companies, with the remark that it applies only to those issuing bodies who, according to the previous research results, were classified into the group of companies that openly informed about the dividend policy (Figure 5). The research included a reference in the description of the dividend policy to net profit (regardless of whether it was related to the unit or to consolidated profit), investment expenditure and available cash. The latter were often combined in the characteristics of the dividend policy with the need to maintain financial liquidity as determinants of dividend payout (Figure 6).

Most of the analysed capital groups (57.14\%) referred in the described dividend policy to the financial parameter at the net profit and capital expenditure level. In contrast, for the other entities, the distribution of the determinants of dividend policy comprised equally $50 \%$ of net profit and capital expenditure or net profit and available cash. In this group of companies, no determinant of the financial result itself was indicated at the level of net profit in the dividend policy. In the case of the dividend policy of capital groups, the net profit was reported for $23.81 \%$ of the analysed issuing bodies. Referring to the inclusion in the content of the dividend policy of the principles of dividend payout by subsidiary companies of capital groups, it should be stated that this description is practically non-existent. The audited capital groups, except for one case, did not include the rules of intra-group dividend payout in the 


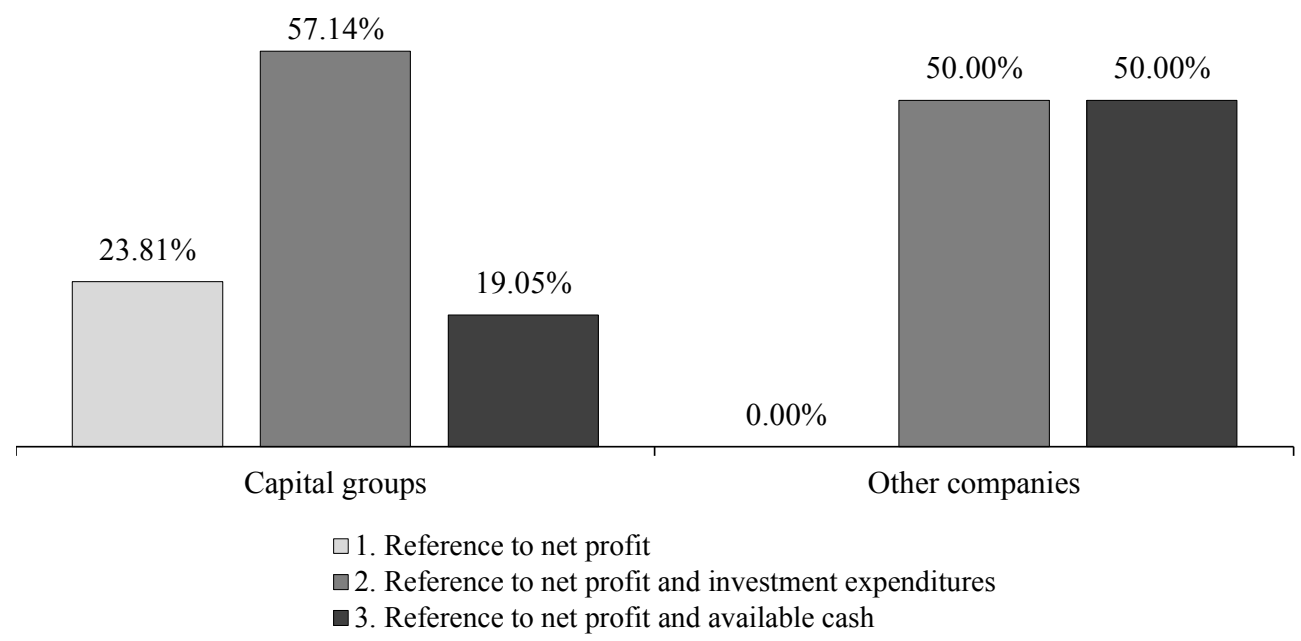

Fig. 6. Characteristics of the dividend policy of capital groups and other companies for 2012-2019

Source: own research.

dividend policy description. Not only was it not described in the manifested dividend policies whether the subsidiary companies paid dividends to the parent company, but it also did not state whether such a dividend policy existed. The exception was Introl $\mathrm{SA}$, which described in the document ${ }^{3}$ the change in the dividend policy within the capital group. It indicated that the parent company would not receive dividends from subsidiary companies due to their investment plans and the need to service capital instalments and interest in the first place. For this reason, Introl SA, as the parent company that coordinates the servicing of the Introl Group's debt, may not have had an adequate pool of funds sufficient to pay dividends to shareholders and required to service loans. Under the new dividend policy, starting from 2018, the decision on a recommendation by the Executive Board to the General Meeting of Shareholders to pay a dividend or refrain from such payout is made after each completed financial year based on financial resources.

When referring to the analysis of Spearman's rank correlation coefficient for capital groups and other companies, it is necessary to point out the strong positive relationship between the average annual rate of return and the cumulative rate of dividends for all the analysed issuing bodies. This dependence is weaker in the case of capital groups (Table 2).

Based on the research on the correlation of selected parameters for both groups of issuing bodies, the relation for capital groups occurred between the average annual rate of return and the cumulative rate of dividends. The result was also confirmed by

3 Current report 10/2018 as of 27 March, 2018, https://www.introlsa.pl/download/raport-biezacy102018-dn-27-marca-2018-r-introl-s-a-zmiana-polityki-dywidendowej/ 
Table 2. Spearman's rank correlation coefficient and Pearson's linear correlation of capital groups and other companies

\begin{tabular}{|l|c|c|c|c|c|}
\hline \multicolumn{7}{|c|}{ Spearman's rank correlation coefficient } \\
\hline Analysed parameters & A:B & A:C & A:D & B:C & B:D \\
\hline Capital groups & 0.14 & 0.29 & 0.79 & -0.20 & 0.24 \\
\hline Other companies & 0.50 & -1.00 & 0.90 & -0.50 & 0.80 \\
\hline \multicolumn{7}{|c|}{ Pearson's linear correlation coefficient } \\
\hline Analysed parameters & A:B & A:C & A:D & B:C & B:D \\
\hline Capital groups & 0.01 & 0.16 & 0.76 & -0.14 & 0.01 \\
\hline Other companies & -0.02 & -0.46 & 0.98 & -0.40 & 0.18 \\
\hline
\end{tabular}

where: A: Average annual rate of return (\%); B: Average annual dividend growth rate (\%); C: Total dividends (PLN); D: Cumulative rate of dividends (\%).

Source: own research.

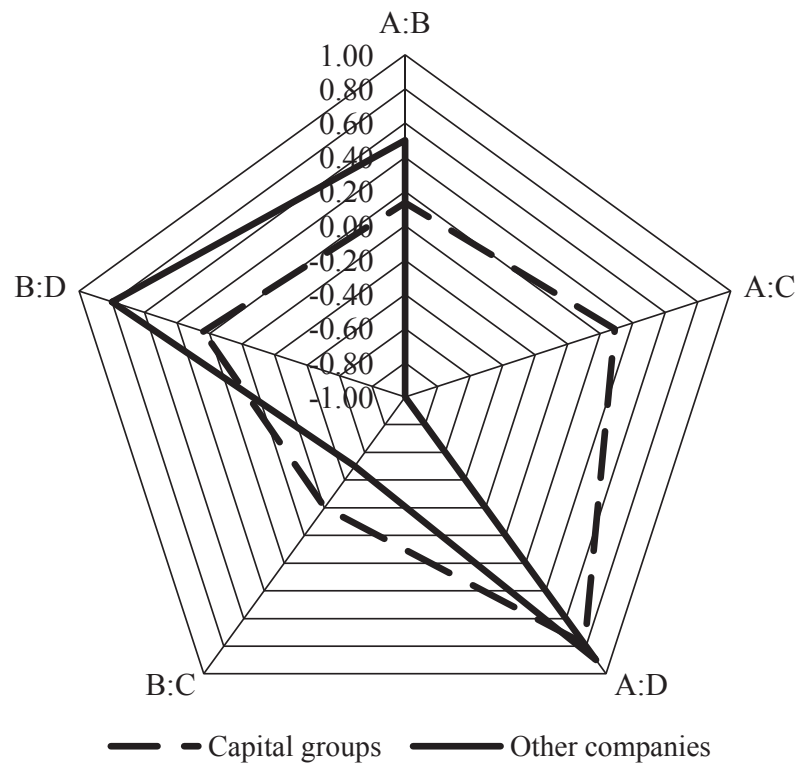

Fig. 7. Radar chart of Spearman's rank correlation coefficient for the analysed parameters for 2012-2019

Source: own research.

Pearson's linear correlation coefficient. The adopted significance level of $\alpha=0.05$ was the only statistically significant relationship for capital groups. This dependence also occurred in the case of other companies. Additionally, there was also a positive relation between the average annual dividend growth rate and the cumulative rate of dividends in the case of other companies. However, this relation for the adopted significance level $\alpha=0.05$ was not confirmed by Pearson's linear correlation coefficient (Figures 7 and 8). 


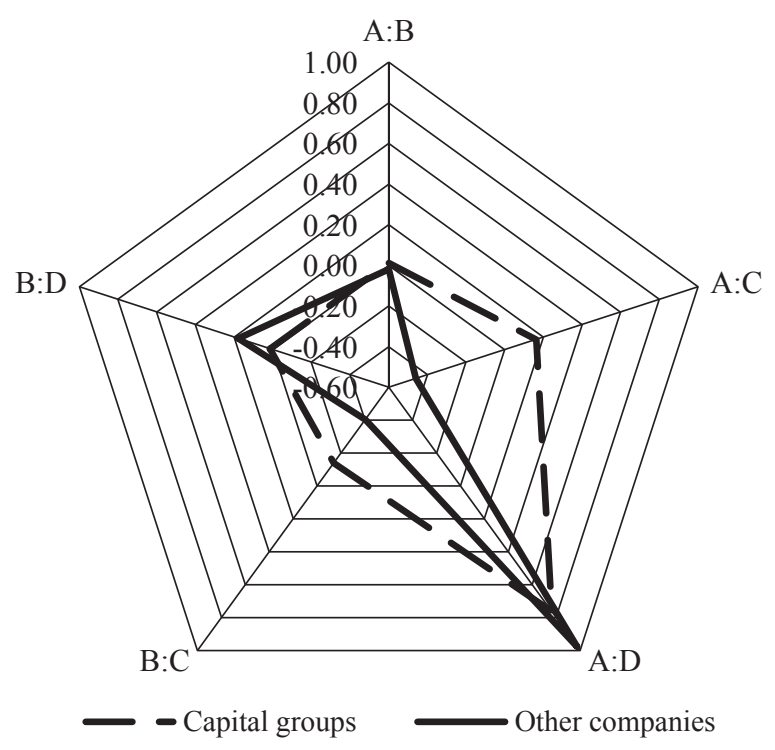

Fig. 8. Radar chart of Pearson's linear correlation coefficient for the analysed parameters for 2012-2019 Source: own research.

\section{Discussion and conclusions}

The conducted research of companies (dividend capital groups and other dividend companies) listed on the Warsaw Stock Exchange, which paid dividends in 20122019, allows for indicating different characteristics of both groups of issuing bodies manifested in the dividend policies. First of all, capital groups are characterized by a higher average annual dividend growth rate than companies that publish only separate financial statements. The latter, in turn, can boast a higher average cumulative rate of dividends if quotations from the beginning of 2012 are indicated as the purchase price. It is worth adding that capital groups pay lower dividends in relation to share prices (regardless of whether the average cumulative rate of dividends or the median of this parameter was used as a measure) with a simultaneous higher average annual dividend growth rate. These conclusions can be used as recommendations for individual or institutional investors investing capital in dividend companies.

Due to the aim of the research and the adopted hypotheses, the third stage of the research is more important, as it included a comparison of the dividend policy of the analysed groups of companies and the direction and strength of the relations between changes in the average annual rate of return, average annual dividend growth rate, total dividends and the cumulative rate of dividends. A clearly described dividend policy characterizes capital groups to a greater extent than other companies. Parent companies are more likely to describe the methods of distributing the financial result 
on their websites or in other documents. Additionally, to a lesser extent, this group of analysed companies does not declare dividends. In this case, up to $60 \%$ of companies not classified as capital groups are characterized by no dividend payout declarations. It can be concluded that capital groups usually openly inform about the dividend policy applied, and they do it more willingly than other companies.

Yet, when analysing the determinants of the dividend policy of the analysed entities, it is possible to point to those that are most often indicated by the issuing bodies. Capital groups mostly make dividend payouts dependent on net profits and capital expenditures, and other companies equally on net profits and capital expenditures or on net profits and available cash. In this group of companies, no determinant of the financial result itself was indicated at the level of net profit.

However, the conclusions regarding the provisions of the dividend policy of capital groups regarding subsidiary companies are surprising. The conducted research shows that parent companies do not report whether they receive dividends from their subsidiary companies, or if the dividend policy of the parent companies also applies to subsidiary companies. Based on Spearman's rho analysis and Pearson's linear correlation coefficient for the analysed companies, it was found that there was:

a) a statistically significant correlation for capital groups between the average annual rate of return and the cumulative rate of dividends,

b) a statistically significant correlation for other companies between the average annual rate of return and the cumulative rate of dividends,

c) in the case of the remaining companies, there was a positive relation between the average annual dividend growth rate and the cumulative rate of dividends, and for the adopted significance level of $\mathrm{p}=0.05$, Pearson's linear correlation coefficient was not confirmed.

On the basis of the conducted Spearman's rho research, no strong correlation for capital groups was indicated between the average annual rate of return and the average annual rate of dividend growth and the sum of dividends. It is worth noting that Pearson's linear correlation coefficient mostly confirmed Spearman's rank indications.

Thus, the adopted research hypotheses were verified, and on this basis, it was concluded that:

$\mathrm{H}_{1}$ : Capital groups listed on the Warsaw Stock Exchange do not refer in their dividend policy to the rules of dividend payout by subsidiary companies. This may mean that they treat this as confidential or that they do not have a developed dividend policy for subsidiary companies.

$\mathrm{H}_{2}$ : Dividend capital groups, due to the greater cash flow possibilities between the group companies, are characterized by a higher average annual dividend growth rate than other companies, but not the cumulative rate of dividends. This means that on average, capital groups paid lower dividends in relation to the quotation 
prices at the beginning of the analysed period than other companies, but in their case, the dividend growth dynamics was higher.

$\mathrm{H}_{3}$ : The correlation coefficient of Spearman's rank of the average annual rate of return with the cumulative rate of dividends for capital groups shows a stronger correlation than in the case of other companies. This means that regarding capital groups, the cumulative rate of dividends does not significantly affect the average annual rate of return to the same extent as in the case of other companies. For capital groups, the average annual rate of return and the average cumulative rate of dividends are lower than for other companies.

Based on the verification of the adopted hypotheses and the comparisons made, it is possible to additionally indicate recommendations regarding the attractiveness of investing in dividend companies - capital groups or companies without related entities. First of all, in the analysed period, capital groups were characterized by a lower average annual rate of return and paid lower dividends (lower average cumulative rate of dividends). On this basis, it can be concluded that dividend companies not classified as capital groups may generate higher rates of return in the investor's portfolio, and, additionally, higher reinvested dividends will increase the efficiency of such investment. Investors should therefore consider such dividend companies in their investment portfolios. It is important to point out the limitations of the study regarding the number of dividend companies due to the selection of companies that paid out dividends without interruption.

\section{References}

Al-Nawaiseh, M. (2012). Dividend policy and ownership structure: An applied study on industrial companies in Amman Stock Exchange. Journal of Management Research, 5(2), 83-106. Retrieved March 8, 2021 from https://www.researchgate.net/publication/267763337_Dividend_Policy_and Ownership_Structure_An_Applied_Study_on_Industrial_Companies_in_Amman_Stock_Exchange

Altshuler, R., \& Gruber, H. (2003). Repatriation taxes, repatriation strategies and multination financial policy. Journal of Public Economics, 87, 73-107.

Brav, A., Graham, J. R., Harvey C. R., \& Michaely, R. (2005). Payout policy in the 21 st century. Journal of Financial Economics, (77).

Brigham, E. F., \& Houston, J. F. (2015). Zarzadzanie finansami. Warszawa: PWN.

Chetty, R., \& Saez, E. (2005). Dividend taxes and corporate behavior: Evidence from the 2003 dividend tax cut. The Quarterly Journal of Economics, 120(3), 791-833.

DeAngelo, H., DeAngelo, L., \& Skinner, D. (2000). Special dividends and the evolution of dividend signaling. Journal of Financial Economics, (57).

Desai, M. A., Foley, C. F., \& Hines Jr, J. R. (2001). Repatriation taxes and dividend distortions. National Tax Journal, 54, 829-851.

Desai, M. A., Foley, C. F., \& Hines Jr, J. R. (2002). Dividend policy inside the firm. Retrieved March 2, 2021 from https://www.nber.org/papers/w8698

Desai, M. A., Foley, C. F., \& Hines Jr, J. R. (2006). Capital controls, liberalizations, and foreign direct investment. Review of Financial Studies, 19. 
Desai, M. A., Foley, C. F., \& Hines Jr, J. R. (2007). Dividend policy inside the multinational firm. Financial Management, 36(1), 5-26.

Dziawgo, D. (2011). Relacje inwestorskie. Warszawa: PWN.

Eije von, J. H., \& Megginson, W. L. (2006). Dividend policy in the European Union. Retrieved February 5, 2021 from http://ssrn.com/abstract $=891035$

Fama, E. F., \& French, K. R. (2001). Disappearing dividends: Changing firm characteristics or lower propensity to pay? Journal of Financial Economics, 60. Retrieved March 5, 2021 from http:// www.sciencedirect.com/science/article/pii/S0304405X01000381/pdfft?md5=3dc1d70baca72a1dc98a59a4a4be8044\&pid=1-s2.0-S0304405X01000381-main.pdf

Goldman, E., \& Viswanath, P. V. (2017). Internal capital markets, forms of intragroup transfers, and dividend policy: Evidence from Indian corporations. Journal of Financial Research, 40(4), 567-610. Retrieved March 8, 2021 from https://ideas.repec.org/a/bla/jfnres/v40y2017i4p567-610.html

Goplan, R., Nanda, V., \& Seru, A. (2014). Internal capital market and dividend policies: Evidence from business groups. The Review of Financial Studies, 27(4), 1102-1142. Retrieved March 8, 2021 from https://www.jstor.org/stable/24465388?seq=1

Głodek, Z. (2004). Zarzadzanie finansami przedsiębiorstw. Warszawa: PWE.

Gmytrasiewicz, M., \& Karmańska, A. (2006). Rachunkowość finansowa. Warszawa: Difin.

Grullon, G., \& Ikenberry, D. L. (2000). What do we know about stock repurchase? Journal of Applied Corporate Finance, 13(1). Retrieved March 1, 2021 from http://burridgecenter.colorado.edu/html/ images/Guest_Speakers/jacfsurvey.pdf

Horbaczewska, B. (2012). Wypłaty dla akcjonariuszy a wycena akcji na rynku kapitatowym. Warszawa: CeDeWu.

Jabłoński, B. (2018). Regularność wypłaty dywidend przez spółki notowane na Giełdzie Papierów Wartościowych w Warszawie za okres 2009-2018. Studia Ekonomiczne Zeszyty Naukowe Uniwersytetu Ekonomicznego w Katowicach, Wspótczesne Finanse, 16(374).

Jabłoński, B. (2019). Characteristics and realization of the dividend policy of companies quoted on the Warsaw Stock Exchange for the period 2008-2017. Financial Sciences, 24(3).

Jacob, M., \& Jacob, M. (2013). Taxation, dividend and share repurchases: Taking evidence global. Journal of Financial and Quantitative Analysis, 48(04), 1-46. Retrieved February 15, 2021 from http://www.nek.uu.se/Pdf/wp201010ucfs.pdf

Jagannathan, M., Stephens, C. P., \& Weisbach, M. S. (2000). Financial flexibility and the choice between dividends and stock repurchases. Journal of Financial Economics, (57). Retrieved March 2, 2021 from http://fisher.osu.edu/supplements/10/10821/stephensjag.pdf.03.2021).

Kari, S., Karikallio, H., \& Pirttilä, J. (2009). The impact of dividend taxation on dividends and investment: New evidence based on a natural experiment (CESifo Working Paper Series No. 2756, 1-41). Retrieved February 5, 2021 from http://papers.ssrn.com/sol3/papers.cfm?abstract_id=1458882

Kowerski, M. (2011). Ekonomiczne uwarunkowania decyzji o wyptatach dywidend przez spótki publiczne. Kraków-Rzeszów-Zamość: Konsorcjum Akademickie Wydawnictwo WSE w Krakowie, WSIiZ w Rzeszowie i WSZiA w Zamościu.

Lahbane, N. B. (2019). Dividend policy in India: Standalone versus business group-affiliated firms. Global Business Review, 20(1), 133-150. Retrieved March 8, 2021 from https://journals.sagepub. com/doi/full/10.1177/0972150918803990

Łukasik, G. (2013). Relacje inwestorskie spółek kapitałowych. Warszawa: Difin.

Łukasik, G., \& Błach, J. (2016). Strategie finansowe przedsiębiorstwa. Katowice: Wydawnictwo Uniwersytetu Ekonomicznego.

Machała, R. (2011). Zarzadzanie finansami i wycena firmy. Wrocław: Oficyna Wydawnicza Unimex.

Piątkowska, J. (2019). Realizacja polityki dywidendy w spółkach kapitałowych - zróżnicowanie sektorowe i własnościowe. Studia Ekonomiczne Zeszyty Naukowe Uniwersytetu Ekonomicznego w Katowicach, Wspótczesne Finanse, 17(380), 77. 
Raport bieżacy 10/2018 z dn. 27 marca 2018 r. (n.d.). Retrieved February 11, 2021 from https://www. introlsa.pl/download/raport-biezacy-102018-dn-27-marca-2018-r-introl-s-a-zmiana-polityki-dywidendowej

Sierpińska, M. (1999). Polityka dywidend w spółkach kapitałowych. Warszawa-Kraków: PWN.

Sopata, M., Mikić, M., \& Horvatinović, T. (2019). Dividend policies and business groups: The case of Croatia. Zagreb International Review of Economics \& Business, 22, 25-36. Retrieved March 8, 2021 from https://ideas.repec.org/a/zag/zirebs/v22y2019iscip25-36.html

Szablewski, A., \& Tuziemek, R. (2006). Wycena i zarzadzanie wartościa firmy. Warszawa: Poltext.

Tuzimek, R. (2013). Decyzje finansowe w spótkach giełdowych a wartość akcji. Warszawa: Oficyna Wydawnicza Szkoła Główna Handlowa.

Wrońska-Bukalska, E. (2018). The power of an overconfident CEO and dividend payment. Journal of Management and Financial Science, XIII(35).

\section{Appendix 1 - the list of companies included in the sample}

1. Ambra

2. Amator

3. AssecoBs

4. AssecoPol

5. AssecoSEE

6. ATMGrupa

7. Budimex

8. $\mathrm{CCC}$

9. CEZ

10. Dębica

11. Decora

12. DomDev

13. Efekt

14. Eurocash

15. Eurotel

16. Fasing

17. Handlowy

18. Hydrotor
19. Introl

20. Kety

21. Kruszwica

22. LPP

23. Neuca

24. Pekao

25. Puławy

26. PZU

27. Rafamet

28. Sanok

29. Snieżka

30. Stalprodukt

31. Stalprofil

32. Talex

33. Unibep

34. Wawel

35. Żywiec

\section{POLITYKA DYWIDEND GRUP KAPITALOWYCH ORAZ INNYCH PODMIOTÓW NOTOWANYCH NA GIEŁDZIE PAPIERÓW WARTOŚCIOWYCH W WARSZAWIE - WYNIKI BADAŃ}

Streszczenie: Celem artykułu było przedstawienie badań dotyczących charakterystyki polityki dywidendowej grup kapitałowych i innych spółek dywidendowych notowanych na Giełdzie Papierów Wartościowych w Warszawie, które wypłacały dywidendy w latach 2012-2019, oraz podjęcie krytycznej oceny. Badania dotyczą sposobów opisu polityki dywidend realizowanej przez spółki notowane na Giełdzie Papierów Wartościowych w Warszawie, które publikują skonsolidowane sprawozdania finansowe (grupy kapitałowe), oraz mierników systemu wypłaty dywidend przez te podmioty. Na podstawie 
przeprowadzonych badań należy stwierdzić, że grupy kapitałowe charakteryzują się wyższą średnią roczną stopą wzrostu dywidendy niż spółki publikujące jedynie jednostkowe sprawozdania finansowe, natomiast te ostatnie mogą pochwalić się wyższą średnią skumulowaną stopą dywidendy. Z przeprowadzonych badań wynika, że spółki dominujące nie wykazują, czy otrzymują dywidendy od spółek zależnych. Jednak na podstawie analizy współczynnika Rho Spearmana oraz współczynnika korelacji liniowej Pearsona dla analizowanych spółek stwierdzono, że dla grup kapitałowych i pozostałych spółek istnieje statystycznie istotny związek pomiędzy średnioroczną stopą zwrotu a skumulowaną stopą dywidendy, a jedynie dla pozostałych spółek pozytywny związek pomiędzy średnioroczną stopą wzrostu dywidendy a skumulowaną stopą dywidendy (nie zostało to jednak potwierdzone współczynnikiem korelacji liniowej Pearsona). Wartością dodaną i aplikacyjną są rekomendacje dotyczące atrakcyjności inwestowania w spółki dywidendowe - grupy kapitałowe lub spółki bez podmiotów powiązanych.

Słowa kluczowe: grupa kapitałowa, polityka dywidend, determinanty polityki dywidend, współczynnik korelacji rang Spearmana. 